\title{
Non-hormonal male contraception: A review and development of an Eppin based contraceptive
}

\author{
Michael G. O'Rand ${ }^{\mathrm{a}, \mathrm{b}, *}$, Erick J.R. Silva ${ }^{\mathrm{c}}$, Katherine G. Hamil ${ }^{\mathrm{b}}$ \\ a Department of Cell Biology \& Physiology, University of North Carolina at Chapel Hill, Chapel Hill, NC 27599, United States \\ b Eppin Pharma Inc., Chapel Hill, NC, 27514, United States \\ c Department of Pharmacology, Instituto de Biociências de Botucatu, Universidade Estadual Paulista, Botucatu, SP 18618-970, Brazil
}

\section{A R T I C L E I N F O}

Available online 22 November 2015

\section{Keywords:}

EPPIN

Male contraception

Sperm

Semenogelin

Reproductive pharmacology

\begin{abstract}
A B S T R A C T
Developing a non-hormonal male contraceptive requires identifying and characterizing an appropriate target and demonstrating its essential role in reproduction. Here we review the development of male contraceptive targets and the current therapeutic agents under consideration. In addition, the development of EPPIN as a target for contraception is reviewed. EPPIN is a well characterized surface protein on human spermatozoa that has an essential function in primate reproduction. EPPIN is discussed as an example of target development, testing in non-human primates, and the search for small organic compounds that mimic contraceptive antibodies; binding EPPIN and blocking sperm motility. Although many hurdles remain before the success of a non-hormonal male contraceptive, continued persistence should yield a marketable product.
\end{abstract}

(C) 2015 Elsevier Inc. All rights reserved.

\section{Contents}

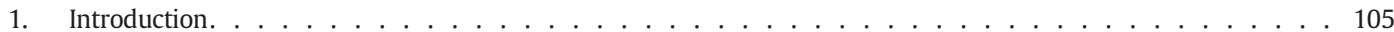

2. Male contraception . . . . . . . . . . . . . . . . . . . . . . . . 106

3. Milestones . . . . . . . . . . . . . . . . . . . . . . . . . . 106

4. Current pharmacologic prospects . . . . . . . . . . . . . . . . . . . 106

5. Development of EPPIN as a contraceptive target . . . . . . . . . . . . . . . . . . . . . . 107

6. Development of a therapeutic agent to selectively and reversibly modulate EPPIN's function . . . . . . . . . 107

7. Optimizing the lead compound . . . . . . . . . . . . . . . . . . . . . . . . . . . 108

8. Prospects for success . . . . . . . . . . . . . . . . . . . . . . . . . . . . . . . 109

Conflict of interest statement ． . . . . . . . . . . . . . . . . . . . . . . . . . . . . . . 109

References . . . . . . . . . . . . . . . . . . . . . . . . 109

\section{Introduction}

Male contraception began with the use of the condom and dates to ancient times in Imperial Rome (Youssef, 1993). Today the condom is still in use and is one of only two methods available to men, aside from early withdrawal, which is always problematic. Vasectomy for contraception, the second method available, is a more recent invention that was initially

Abbreviations: Amino acids: Y, tyrosine; $\mathrm{Q}$ glutamine; N, asparagine; $\mathrm{H}$, histidine; $\mathrm{E}$, glutamic acid; S, serine; K, lysine; V, valine; T, threonine; L, leucine; C, cysteine; P, proline; A, alanine; D, aspartic acid; CAS, CRISPER-associated genes; CASA, computerassisted sperm analysis; IC50, inhibitor concentration at 50\% level; VSL, the average velocity measured in a straight line from the beginning to the end of the sperm track in $\mu \mathrm{m} / \mathrm{sec}$; RMI, relative motility inhibition; PSA, prostate specific antigen.

* Corresponding author. Tel.: 9196082984.

E-mail address: morand@eppin.com (M.G. O'Rand). for criminals and other degenerates (Ochsner, 1899, 1925). Today these two methods persist; men still have two choices for contraception, the condom and vasectomy. Perhaps it is time for something new?

During the early years of the 20th century human reproduction was not well understood and research progress in reproduction awaited the discovery and mechanistic understanding of human hormones. When the effects of progesterone on ovulation were reported in 1937 (Makepeace et al., 1937) the stage was set for the research and developmental efforts that led to the FDA approval of Enovid in 1957, for infertility and menstrual irregularities, and by 1960 as a birth control pill (Eig, 2014). The marketing of Enovid by G.D. Searle \& Co., which evolved into the modern birth control "pill", focused the interest of the pharmaceutical industry, and indeed much of academic research in reproduction, on understanding hormonal regulation of the reproductive system. Reproductive endocrinologists had a target and a ligand to study. 


\section{Male contraception}

Research work on male contraception began with a search for easy targets specific to the male aiming to disrupt sperm or testis function. In the context of the success of the female "pill" the most obvious choice was a hormonal approach in which testosterone or its analogues were used to inhibit testicular steroidogenesis as a means to block spermatogenesis. Non-hormonal targets for contraception however, were not obvious and much more difficult to define. Early workers (Landsteiner, 1899; Henle et al., 1938; Tyler, 1948) interested in identifying and studying the function of sperm proteins (antigens) utilized the immunogenicity of spermatozoa and the specificity of the resulting antisera (Tyler, 1961) as probes for function (O'Rand \& Metz, 1974); with the hope of finding a contraceptive target. Spermatogenesis, a highly ordered process that occurs inside the protection of the bloodtestis barrier (Waites \& Setchell, 1969; Dym \& Fawcett, 1970; Vitale et al., 1973), presented an abundance of male specific proteins that might become targets for contraception (O'Rand \& Romrell, 1977). With the realization that infertility patients often had anti-sperm antibodies (Rümke \& Hellinga, 1959), the idea developed that sperm proteins synthesized in the testis, might be the basis for the development of a contraceptive. This in turn led to early attempts to find sperm proteins (antigens) that would serve as contraceptives in women (Metz, 1978; Morton \& McAnulty, 1979; Munoz \& Metz, 1978). Finding contraceptives for men on the other hand, did not generate any scientific interest aside from studies in guinea pigs and humans, whose focus was on the concerns of developing autoimmune orchitis as a result of male contraception (Mancini, 1976).

In the 1970s and 1980s interest in developing contraceptives for men focused largely on the study of plant extracts known to affect fertility. Extracts of Justicia gendarussa (Prajogo et al., 2009) and Tripterygium wilfordii (Zhen et al., 1995), as well as gossypol (Liu et al., 1987a,b), an extract of cottonseed, all have been studied as possible male contraceptives. Unfortunately plant extracts by their very nature suffer from a lack of specificity and attempts at purification and synthesis of the "active" ingredient have often presented unacceptable toxicology profiles or led to irreversible infertility.

In spite of progress in identifying sperm protein structure and function, understanding the functional significance of these male targets had to await advances in molecular biology and its associated technologies. Most notably the advent of mouse "knockout" technology allowed the function of a protein to be studied by disrupting the expression of its gene. One of the first knockouts to disrupt reproduction related functions was the estrogen receptor gene, affecting both male and female fertility (Lubahn et al., 1993). Studies disrupting male specific genes demonstrated that loss of function of testis or epididymal specific proteins could lead to male-specific infertility (Dix et al., 1996; Kastner et al., 1996; Sonnenberg-Riethmacher et al., 1996). Removing a specific gene from expression in the testis or epididymis with subsequent fertility testing allowed a very specific conclusion; namely that the removed protein was essential for fertility. For example the targeted disruption ("knockout") of the CatSper gene (Ren et al., 2001) during spermatogenesis and therefore in developing spermatozoa demonstrated the essential function of calcium channels in sperm motility and mouse fertility. The recently developed CRISPR (clustered regularly interspaced short palindromic repeat)-CAS technology may allow further refinement of gene manipulation to target testis or sperm specific proteins (Archambeault \& Matzuk, 2014).

\section{Milestones}

Today any identification and characterization of a contraceptive candidate must include a demonstration of essential function in fertility. Consequently a list of critical questions or milestones can be developed for putative contraceptive targets that follow from the demonstration of essential function. Is the function specific to the testis, the epididymis, or spermatozoa? For example one could imagine the function being transmembrane ion currents (e.g. Breton et al., 1996; Kirichok et al., 2006), an enzyme activity (e.g. GAPDHS (Miki et al., 2004); LDH-C4 (Odet et al., 2008)), a protein-protein binding event (O'Rand et al., 2004), a transmembrane receptor signaling (Gottwald et al., 2006; White et al., 2013), or a protein-nucleic acid binding event (Matzuk et al., 2012). Having identified an essential function, can it be blocked reversibly? Drugs such as ion channel blockers, receptor antagonists and enzyme inhibitors immediately come to mind. The next question is: Can an assay be established to measure the effects of blocking the target's function on fertility? To answer this question, establishing a phenotypic assay is a crucial milestone because it enables the search for a therapeutic agent to specifically and reversibly block the function. Finally the putative contraceptive target needs to be understood at a molecular level, to have the mechanism of action characterized such that future investors in the technology are convinced of the specificity and reversibility.

\section{Current pharmacologic prospects}

Although there is no shortage of putative contraceptive targets for men, the actual number under development has been limited because of the availability of funding and the necessity of meeting the required milestones. Luckily a number of therapeutic agents have been identified while being tested for other applications. For example lonidamine drugs were first anticancer therapeutics but their derivatives became Adjudin (Cheng et al., 2002; Cheng et al., 2005) and Gamendazole (Tash et al., 2008a; 2008b), both of which disrupt spermatogenesis by interference with Sertoli cell function. The indenopyridines, particularly l-CDB4022 (originally RTI-4587-073 from RTI in Research Triangle Park, $\mathrm{NC}$ ), have been tested for contraceptive effectiveness, and in nonhuman primates the disruption of Sertoli cell function proved to be reversible (Hild et al., 2007). The disruption of Sertoli cell function, particularly with Gamendazole, which has been studied in some detail (Tash et al., 2008a,b), brings into focus a number of important questions related to the contraceptive milestones discussed above. 1) What is the mechanism of action and is it specific to the testis? If Gamendazole only affects a subset of functions of HSP90AB1 and EEF1A1 as reported (Tash et al., 2008b), how will this affect the therapeutic window over long time courses of administration? This is worrying because in rats $3 \mathrm{mg} / \mathrm{kg}$ (single oral dose) results in complete recovery but not complete infertility while $6 \mathrm{mg} / \mathrm{kg}$ results in 100\% infertility but only $57 \%$ recovery (Tash et al., 2008a). The window is rather narrow for complete inhibition of spermatogenesis and reversibility. 2) What are the long term effects of disrupting the apical ectoplasmic specializations in Sertoli cells over several months or years? Daily treatment with $6 \mathrm{mg} / \mathrm{kg}$ Gamendazole for 7 days further reduced fertility recovery to 29\% (Tash et al., 2008a); further suggesting that longer treatment with this drug may render males sterile. 3) Would autoimmune orchitis eventually develop as a result of the immune system's exposure to sluffed-off spermatids? 4) Perhaps of a more general concern when Sertoli cells are disrupted, what is the actual effect on male hormones? In vivo serum levels of inhibin B fall below measurable levels, which in turn affects FSH (Tash et al., 2008b); is this really a hormonal contraceptive? Until a more favorable toxicology profile can be demonstrated, testing in non-human primates seems premature. Whether these and other therapeutics that act on the disruption of Sertoli cell function and in particular Sertoli-germ cell junctions can be developed into marketable drugs remains to be seen (Boekelheide et al., 2005).

A more recent and most promising therapeutic agent for male contraception was reported by the Matzuk and Bradner laboratories in 2012 (Matzuk et al., 2012), utilizing the anti-cancer agent JQ1, which targets bromodomain (BRD) containing proteins. The testis specific form (BRDT) would meet target specificity, drugability and essential function requirements. What remains is the non-trivial task of translation from 
mice to men. If this exciting new therapeutic can specifically target BRDT in humans then male contraception will have made a significant advance. Since the human genome encodes several BRD containing proteins, such as BRD2, BRD3 and BRD4 (Berkovits \& Wolgemuth, 2013; Sanchez \& Zhou, 2009), the development of highly selective BRDT ligands will be important to avoid potential side effects due to inhibition of its somatic isoforms. Additional therapeutic agents, discovered in the late twentieth century have recently been re-investigated; including WIN 18,446 (Amory et al., 2011) which inhibits ALDH1a2 that converts vitamin A into retinoic acid. Although treatment with WIN 18,446 completely stops spermatogenesis and appears reversible given sufficient time, there should be serious concern with systemic effects that WIN 18,466 may have on obesity and lipidosis (Paik et al., 2014). BMS-189453 (Chung et al., 2011), which inhibits retinoic acid receptors from binding retinoic acid, has been shown to inhibit spermatogenesis through its effect on spermatids and the eventual loss of germ cells. As discussed above, the long term effects on Sertoli cells and the possibility of autoimmune orchitis need to be considered. Two additional antagonists, BMS189532 and BMS-195614, which have effects in in vitro assays, have been tested in vivo for their effects on spermatogenesis and found to have no effect (Chung et al., 2013); pointing out the importance of drug design and in vivo testing. While these studies are encouraging it remains to be determined whether drugs that disrupt spermatogenesis can avoid targeting stem cells or Leydig cell function, and can be administered over long time periods without cumulative off target side effects. A contraceptive that disrupts spermatogenesis will necessitate long precontraceptive and post-contraceptive wait times as at least 72 days are required for spermatogonia to differentiate and reach the cauda epididymides as mature spermatozoa. An approximate 90 day wait period to achieve the full contraceptive effectiveness may not appeal to some men and could increase the risks of failure and decrease therapeutic compliance.

Recent advancements in our understanding of sperm physiology, including calcium channels and metabolism (CatSper: Kirichok et al., 2006; Lishko et al., 2012; GAPDHS: Miki et al., 2004; LDH-C4: Odet et al., 2008), have brought spermatozoa back into consideration as putative contraceptive targets. However, the downside of many sperm-specific proteins is that they are only slight variations of somatic proteins. This creates a difficult situation in which that "slight variation" must be exploited to make the drug sperm specific. The study of protein-protein interactions on the surface of ejaculate spermatozoa expanded the scope of sperm targets for male contraception (Wang et al., 2005; Wang et al., 2007). If specific inhibitors for these sperm functions can be demonstrated for human spermatozoa then they would represent a new class of therapeutic agents that would not require disruption of spermatogenesis. Moreover they could be applied to spermatozoa in either males or females giving them a distinct advantage over other contraceptive agents. Thus, exploring sperm-surface targets for male contraceptive drug development has the potential to promote innovation in the field.

\section{Development of EPPIN as a contraceptive target}

As advantageous as "knockout" experiments are in mice, some reproductive functions in primates are not modeled particularly well in rodents. These reproductive functions generally involve maturation, secretory products in the male reproductive tract, and migration in the female tract. Genes with roles in innate immunity and reproduction evolve rapidly by positive Darwinian selection; particularly those associated with the male reproductive tract (Silva et al., 2013; Torgerson et al., 2002; Torgerson \& Singh, 2003; Wyckoff et al., 2000). EPPIN (epididymal protease inhibitor) is an example of a gene in the WFDC gene family whose evolution in the primate lineage has been rapid, driven by sexual function and sperm competition (Ferreira et al., 2013). Our studies on EPPIN and its interacting partner semenogelin (SEMG1) are a recent case in point. The adaptive molecular coevolution of SEMG1 and EPPIN in primates may have rapidly changed their biochemical properties resulting in a gain of function for both proteins (Silva et al., 2013). For these reasons anti-sperm antibodies, studied for the last sixty years, still may provide tools for discovering the function of sperm specific molecules and whether or not they have essential roles in fertility. This is particularly true in primates where creation of a null mutation is not practical. Therefore one strategy for the development of new contraceptives is to utilize immunization of non-human primates with specific sperm surface proteins and determine the effects of the immune response on the ejaculated spermatozoa of immunized males.

Human EPPIN is a single copy gene on chromosome 20 containing six exons that span $7 \mathrm{~kb}$, whose protein contains 133 amino acids and whose expression is androgen dependent (Richardson et al., 2001; O'Rand et al., 2011). We utilized the immunocontraceptive approach to demonstrate that EPPIN has an essential function in reproduction. O'Rand et al. (2004) demonstrated effective and reversible contraception in male monkeys if a high serum anti-EPPIN titer $(>1: 1000)$ was maintained. The key observation in this study was that sperm motility and EPPINSEMG1 binding were inhibited by anti-EPPIN antibodies. In seminal plasma and on human spermatozoa following ejaculation, EPPIN was bound to SEMG1 (Wang et al., 2005; O'Rand et al., 2006) and further studies led to the demonstration that the C-terminal domain of the EPPIN protein contained the critical epitope for both SEMG1 and anti-EPPIN antibody binding (O'Rand et al., 2009; O'Rand et al., 2011).

We now know that EPPIN has at least three physiological functions. Exhibiting strong antibacterial activity (Yenugu et al., 2004) and modulating the proteolytic activity of PSA (prostate specific antigen, a serine protease) against its seminal plasma substrate, SEMG1 (Wang et al., 2007), are two functions that serve to protect spermatozoa from bacterial and proteolytic attack during transit in the female reproductive tract (O'Rand et al., 2011), as well as to modulate PSA activity on SEMG1 bound to EPPIN. Furthermore, EPPIN inhibits sperm motility when it binds SEMG1 on the sperm surface (Mitra et al., 2010). This third physiological function acts as an additional layer of protection in the female reproductive tract by preventing premature hyperactivation and capacitation. The effect of SEMG1 bound to EPPIN on the sperm surface manifests itself as a rapid decrease in internal $\mathrm{pH}$ (within less than $1 \mathrm{~min}$ ) and a decrease in internal calcium levels ( $>30 \%$ decrease with $3 \mu \mathrm{M}$ SEMG1; O'Rand \&Widgren, 2012). Thus the normal cascade of physiological events leading to fertilization, namely an increase in internal sperm $\mathrm{pH}$ which is necessary to activate the CatSper calcium channel which in turn is necessary for hyperactivation and fertility, is disrupted.

Our rationale for selecting EPPIN as a contraceptive target is that it meets our milestones for an ideal contraceptive target: It is specific to the male reproductive system and has an essential function on ejaculate spermatozoa. Its function can be reversibly blocked with easy access to the target on the sperm surface. We have established assays to measure its function (see below) and we have determined its mechanism of action. The selection of EPPIN as a target overcomes any safety concerns regarding targeting spermatogenesis.

\section{Development of a therapeutic agent to selectively and reversibly modulate EPPIN's function}

EPPIN is a male-specific protein found on the surface of human spermatozoa that is essential for fertility in primates. The development of an anti-EPPIN immunocontraceptive, however, is not considered a viable commercial option for a number of reasons including individual efficacy. Therefore we have developed a series of small organic compounds that mimic the effect of anti-EPPIN antibodies binding to the sperm surface, thereby inhibiting sperm motility. As noted above, one of the milestones in developing a male contraceptive is developing an assay to block the essential function. For EPPIN we adapted the AlphaScreen assay (amplified luminescent proximity homogeneous assay, PerkinElmer, Waltham, MA) to look for "hit" compounds that would bind EPPIN and inhibit either anti-EPPIN antibody or SEMG1 
from binding to EPPIN (Silva et al., 2012; O'Rand et al., 2011). As described previously (O'Rand et al., 2011), in our primary compound screen we utilize histidine tagged recombinant human EPPIN attached to NTA-donor beads and anti-EPPIN antibody (S21C; against the EPPIN C-terminal domain) attached to protein A-acceptor beads. In our secondary compound screen we utilize donor beads that bind biotinylated SEMG1 and acceptor beads that bind EPPIN via anti-EPPIN (N-terminal) antibodies and protein A-acceptor beads. This assay allows SEMG1 to bind to its EPPIN binding site on the C-terminal of the EPPIN protein (O'Rand et al., 2011). As a control compound screen we use a Modified TruHits Assay (PerkinElmer) for non-specific bead binding and compound interference with the assay. Promising lead compounds were synthesized and tested for their ability to inhibit human sperm motility (O'Rand et al., 2011). In this live cell compound screen we established a computer-assisted sperm analysis (CASA) for determining the effect of compounds on human sperm motility (Silva et al., 2013). Additionally, to facilitate the IC50 evaluation of compounds using different ejaculates and to reduce inter-assay variation due to differences in sperm quality in different semen samples, an index of relative motility inhibition (RMI) was developed. This is calculated as: RMI $=[\%$ motility $* \mathrm{VSL}]$; percentage of motile sperm (\%motility) multiplied by the straight-line velocity (VSL); the average velocity measured in a straight line from the beginning to the end of a sperm track in $\mu \mathrm{m} / \mathrm{sec}$ as measured by CASA. Structures with IC50s $<100 \mu \mathrm{M}$ in the anti-EPPIN (primary compound screen) and sperm motility assays (live cell compound screen) were considered further by examining their ability to dock into an EPPIN C-terminal 3D model described previously (Silva et al., 2012).

\section{Optimizing the lead compound}

To optimize our lead compounds we characterized SEMG1's binding to EPPIN in order to determine which EPPIN amino acid residues were important for sperm motility inhibition. Using recombinant human SEMG1 fragments and testing each for the inhibition of sperm motility, we found that the SEMG1 sequence E229-Q247 (E2Q) was the minimal sequence necessary to inhibit human sperm motility (Silva et al., 2013). This E2Q sequence (229-E $\left.{ }^{1} \mathrm{HS}^{3} \mathrm{SKVQ}^{7} \mathrm{TS}^{9} \mathrm{LC}^{11} \mathrm{PAHQDKLQ}{ }^{19}-247\right)$ was subsequently modeled in PEP-FOLD (Shen et al., 2014; Thévenet et al., 2012; Maupetit et al., 2009; Maupetit et al., 2010) to produce a 3D peptide model which was subsequently modeled in ClusPro2 (Kozakov et al., 2013; Kozakov et al., 2006; Comeau et al., 2004) to produce a series of structural models to predict the docking of the E2Q peptide into EPPIN's C-terminal region, which contains both SEMG1 and anti-EPPIN antibody interacting surfaces (O'Rand et al., 2004; Silva et al., 2012). Fig. 1A illustrates the EPPIN C-terminal docking site for SEMG1 and C-terminal anti-EPPIN antibodies. Utilizing EPPIN's Y107-F117 loop, which had been shown previously to be the critical site for SEMG1 binding (Silva et al., 2012), and the E2Q peptide, the ClusPro2 docking models were evaluated. The docking results allowed us to map the amino acid residues of EPPIN that bind to the E2Q peptide. Fig. 1B, C illustrate one interaction model containing the peptide in the Y107-F117 binding loop. Examination of the model (Pettersen et al., 2004) revealed 8 apparent $H$-bonds between EPPIN and E2Q in the binding site. Information from SEMG1 peptide binding indicated that the compound should cover a surface area of approximately $8.9 \times 6.5$ Å of the binding site, a relatively large area, although not unexpected for a protein-protein interaction site. We found that the EPPIN residues shown in Table 1 bind specific SEMG1 peptide residues. These EPPIN residues (Y107, N113, N114, N116, Q118, and K120; Table 1) are most likely the critical ones that our lead compound should interact with in order to inhibit sperm motility.

Subsequent experiments with potential contraceptive compounds found this to be the case. As shown in Fig. 2 and Table 2, the test compounds B4, B41, B42, and B4_R1 exhibit various inhibition values (IC50) in all three assays; primary, which assays EPPIN-anti-EPPIN antibody binding (S21C; O'Rand et al., 2011), secondary, which assays
A

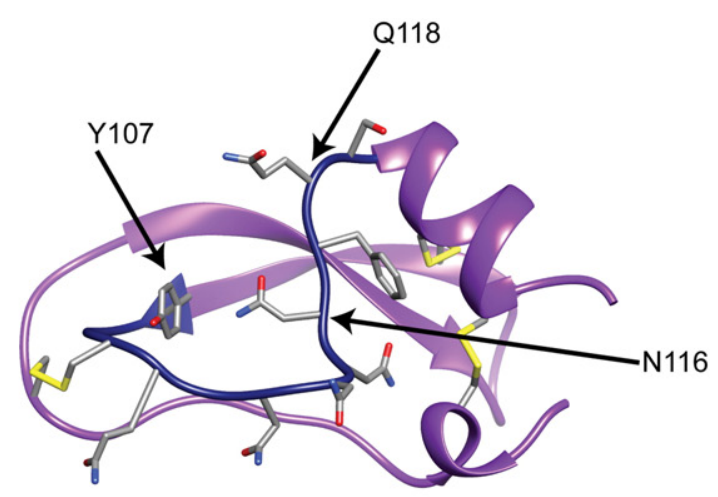

B
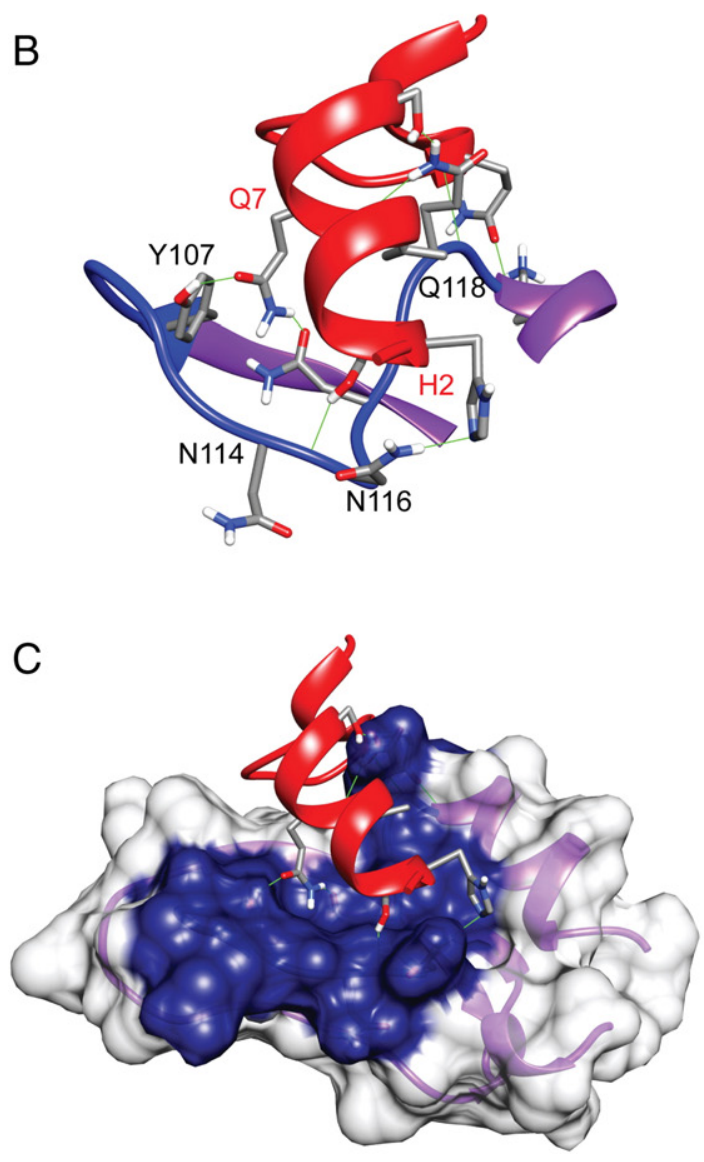

Fig. 1. (A) 3D model of the EPPIN C-terminal with the SEMG1 binding sequence shown in blue. Three of EPPIN's key amino acids within the binding site are indicated by the arrows: Y107, Q118 and N116. (B) The SEMG1 peptide E2Q (red) binding to the EPPIN C-terminal. Green lines indicate H-bonds. Not all the EPPIN-E2Q H-bonds are visible in this view. Q7 and $\mathrm{H} 2$ are E2Q amino acids, see Table 1. (C) The SEMG1 peptide E2Q (red) binding to the EPPIN C-terminal shown in surface view with the docking pocket indicated in blue.

Table 1

Hydrogen bonding between EPPIN and SEMG1 peptide in the binding pocket.

\begin{tabular}{lll}
\hline EPPIN residue & SEMG1 peptide E229-Q247 (1-19) & H-bond \\
\hline Y107 & Q7 & $1.863 \AA$ \\
N113 & S3 & $1.918 \AA$ \\
N114 & H2 & $2.133 \AA$ \\
N116 & Q7 & $1.966 \AA$ \\
Q118 & S9 & $2.093 \AA$ \\
& V6 & $2.05 \AA$ \\
K120 & Q15 & $2.091 \AA$ \\
& Q15 & $1.948 \AA$ \\
\hline
\end{tabular}




\section{Compound B4}<smiles>CCOC(=O)CSc1nc(=O)c(NCC(=O)OC)n[nH]1</smiles>

\section{Compound B4_R1}<smiles>Cc1n[nH]c(SCC(=O)O)nc1=O</smiles>

\section{Compound B41}<smiles>CCOC(=O)CNc1n[nH]c(SCC(=O)OCC)nc1=O</smiles>

\section{Compound B42}<smiles>CCOC(=O)CSc1nc(=O)c(NCC(=O)OC(C)C)n[nH]1</smiles>

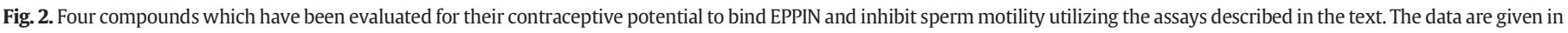
Table 2.

EPPIN-SEMG1 binding, and live cell (CASA), which assays human sperm motility (O'Rand et al., 2011). Compound B4 has a sperm motility IC50 of $11.4 \mu \mathrm{M}$ and forms H-bonds with EPPIN amino acids Y107, N114 and N116 in our docking studies using the SwissDock platform (Grosdidier et al., 2011). Compounds B41 and B42 form fewer Hbonds in the binding pocket and are comparatively less effective in inhibiting sperm motility, while B4-R1 is completely outside the pocket and has no effect on sperm motility. These examples demonstrate that our methodology for identifying contraceptive compounds is effective.

\section{Prospects for success}

Men have two choices for contraception, the condom and vasectomy. The disadvantages of condoms and vasectomies are that vasectomies are not readily reversible and condoms have a high typical use failure rate (Contraceptive Use in the United States, Guttmacher Institute, 2015). Nevertheless, one in three married couples in Australia and New Zealand rely on vasectomy for their contraception, one in six in the United States, and one in twenty worldwide (Sneyd et al., 2001). Condoms account for an additional 13\% of contraceptive use in developed countries. In a study of British men, $80 \%$ placed a hypothetical male pill as one of their top three contraceptive choices (Brooks, 1998) and over $60 \%$ of men in Germany, Spain, Brazil and Mexico were willing to use a new method of male contraception (Heinemann et al., 2005). In 1970 only $15 \%$ of men who were fathering children were over the age of 35 , today it is $25 \%$. This increase in time before a man chooses to become a father demonstrates a need for a new, reliable and reversible means of male contraception. Consequently a new contraceptive for men has a good chance of success in the market. In spite of the need, whether or not any of the new therapeutic agents in the pipeline for male contraception will actually make it to the market cannot be determined at this time. Although the obstacles are numerous, establishing long-term safety and in vivo efficacy, the goal of bringing a new male contraceptive to market will not be met without increased funding and pharmaceutical expertise. Nevertheless, we remain optimistic toward a positive outcome.

\section{Conflict of interest statement}

Dr. Silva has no conflicts of interest to declare. Drs. O'Rand and Hamil have affiliations with Eppin Pharma Inc.

\section{References}

Amory, J. K., Muller, C. H., Shimshoni, J. A., Isoherranen, N., Paik, J., Moreb, J. S., et al. (2011). Suppression of spermatogenesis by bisdichloroacetyldiamines is mediated by inhibition of testicular retinoic acid biosynthesis. J Androl 32(1), 111-119. http:// dx.doi.org/10.2164/jandrol.110.010751.

Table 2

Assays to evaluate potential contraceptive compound function.

\begin{tabular}{|c|c|c|c|c|}
\hline Compound name & B4 & B41 & B42 & B4_R1 \\
\hline \multicolumn{5}{|l|}{ Compound screen } \\
\hline Primary $^{\mathrm{a}}$ & $\begin{array}{l}17.6 \pm 7.8 \\
\mathrm{n}=10\end{array}$ & $\begin{array}{l}15.4 \pm 8.5 \\
\mathrm{n}=3\end{array}$ & $\begin{array}{l}18.9 \pm 16.0 \\
n=3\end{array}$ & $\begin{array}{l}258 \\
n=1\end{array}$ \\
\hline Secondary ${ }^{\mathrm{a}}$ & $\begin{array}{l}11.5 \pm 2.3 \\
\mathrm{n}=10\end{array}$ & $\begin{array}{l}10.0 \pm 2.5 \\
\mathrm{n}=3\end{array}$ & $\begin{array}{l}9.5 \pm 1.8 \\
\mathrm{n}=3\end{array}$ & No activity \\
\hline Live cell ${ }^{\mathrm{a}}$ (CASA) & $\begin{array}{l}11.4 \pm 3.9 \\
\mathrm{n}=3\end{array}$ & $\begin{array}{l}73.5 \pm 20.5 \\
\mathrm{n}=2\end{array}$ & $\begin{array}{l}37.0 \pm 11.3 \\
n=2\end{array}$ & No effect \\
\hline H-bonds to EPPIN ${ }^{b}$ & $\begin{array}{l}\text { Y107 } \\
\text { N114 } \\
\text { N116 }\end{array}$ & $\begin{array}{l}\text { Q118 } \\
\text { N122 }\end{array}$ & N116 & $\begin{array}{l}\text { D96 } \\
\text { K98 }\end{array}$ \\
\hline
\end{tabular}

a IC50 values ( $\mu \mathrm{M})$ for each screen (see text for description).

b EPPIN amino acid residues to which the compound formed H-bonds. 
Archambeault, D. R., \& Matzuk, M. M. (2014). Disrupting the male germ line to find infertility and contraception targets. Ann D'endocrinologie 75(2), 101-108. http://dx.doi. org/10.1016/j.ando.2014.04.006.

Berkovits, B. D., \& Wolgemuth, D. J. (2013). Chapter eleven - The role of the double bromodomain-containing BET genes during mammalian spermatogenesis. In P. M. Wassarman (Ed.), Current Topics in Developmental Biology vol. 102. (pp. 293-326). Academic Press (Retrieved from http://www.sciencedirect.com/science/article/pii/ B9780124160248000118).

Boekelheide, K., Johnson, K. J., \& Richburg, J. H. (2005). Chapter 20 - Sertoli cell toxicants. In M. K. Skinner, \& M. D. Griswold (Eds.), Sertoli cell biology (pp. 345-382). San Diego: Academic Press (Retrieved from http://www.sciencedirect.com/science/article/pii/ B9780126477511500210).

Breton, S., Smith, P. J., Lui, B., \& Brown, D. (1996). Acidification of the male reproductive tract by a proton pumping (H+)-ATPase. Nat Med 2(4), 470-472.

Brooks, M. (1998). Men's views on male hormonal contraception-A survey of the views of attenders at a fitness centre in Bristol, UK. Br J Fam Plann 24(1), 7-17.

Cheng, C. Y., Mo, M. Yun, Grima, J., Saso, L., Tita, B., Mruk, D., et al. (2002). Indazole carboxylic acids in male contraception. Contraception 65(4), 265-268.

Cheng, C. Y., Mruk, D., Silvestrini, B., Bonanomi, M., Wong, C. -H., Siu, M. K. Y., et al. (2005). AF-2364 [1-(2,4-dichlorobenzyl)-1H-indazole-3-carbohydrazide] is a potential male contraceptive: a review of recent data. Contraception 72(4), 251-261. http://dx.doi. org/10.1016/j.contraception.2005.03.008.

Chung, S. S. W., Cuellar, R. A. D., Wang, X., Reczek, P. R., Georg, G. I., \& Wolgemuth, D. J. (2013). Pharmacological activity of retinoic acid receptor alpha-selective antagonists in vitro and in vivo. ACS Med Chem Lett 4(5), 446-450. http://dx.doi.org/10.1021/ $\mathrm{ml} 300365 \mathrm{k}$.

Chung, S. S. W., Wang, X., Roberts, S. S., Griffey, S. M., Reczek, P. R., \& Wolgemuth, D. J. (2011). Oral administration of a retinoic acid receptor antagonist reversibly inhibits spermatogenesis in mice. Endocrinology 152(6), 2492-2502. http://dx.doi.org/10. 1210/en.2010-0941.

Comeau, S. R., Gatchell, D. W., Vajda, S., \& Camacho, C. J. (2004). ClusPro: An automated docking and discrimination method for the prediction of protein complexes. Bioinformatics 20(1), 45-50. http://dx.doi.org/10.1093/bioinformatics/btg371.

Contraceptive Use in the United States (2015). Retrieved August 3, 2015, from http:// www.guttmacher.org/pubs/fb_contr_use.html

Dix, D. J., Allen, J. W., Collins, B. W., Mori, C., Nakamura, N., Poorman-Allen, P., et al. (1996). Targeted gene disruption of Hsp70-2 results in failed meiosis, germ cell apoptosis, and male infertility. Proc Natl Acad Sci U S A 93(8), 3264-3268.

Dym, M., \& Fawcett, D. W. (1970). The blood-testis barrier in the rat and the physiological compartmentation of the seminiferous epithelium. Biol Reprod 3(3), 308-326.

Eig, J. (2014). The Birth of the Pill | W. W. Norton \& Company. W.W. Norton \& Company Inc. Retrieved from http://books.wwnorton.com/books/The-Birth-of-the-Pill/

Ferreira, Z., Seixas, S., Andrés, A. M., Kretzschmar, W. W., Mullikin, J. C., Cherukuri, P. F., et al. (2013). Reproduction and immunity-driven natural selection in the human WFDC locus. Mol Biol Evol 30(4), 938-950. http://dx.doi.org/10.1093/molbev/ mss329.

Gottwald, U., Davies, B., Fritsch, M., \& Habenicht, U. F. (2006). New approaches for male fertility control: HE6 as an example of a putative target. Mol Cell Endocrinol 250(1-2), 49-57. http://dx.doi.org/10.1016/j.mce.2005.12.024.

Grosdidier, A., Zoete, V., \& Michielin, O. (2011). SwissDock, a protein-small molecule docking web service based on EADock DSS. Nucleic Acids Res 39(Suppl. 2), W270-W277. http://dx.doi.org/10.1093/nar/gkr366.

Heinemann, K., Saad, F., Wiesemes, M., White, S., \& Heinemann, L. (2005). Attitudes toward male fertility control: Results of a multinational survey on four continents. Hum Reprod 20(2), 549-556. http://dx.doi.org/10.1093/humrep/deh574.

Henle, W., Henle, G., \& Chambers, L. A. (1938). Studies on the antigenic structure of some mammalian spermatozoa. J Exp Med 68(3), 335-352. http://dx.doi.org/10.1084/jem. 68.3.335.

Hild, S. A., Reel, J. R., Dykstra, M. J., Mann, P. C., \& Marshall, G. R. (2007). Acute adverse effects of the indenopyridine CDB-4022 on the ultrastructure of Sertoli cells, spermatocytes, and spermatids in rat testes: Comparison to the known Sertoli cell toxicant din-pentylphthalate (DPP). J Androl 28(4), 621-629. http://dx.doi.org/10.2164/jandrol. 106.002295

Kastner, P., Mark, M., Leid, M., Gansmuller, A., Chin, W., Grondona, J. M., et al. (1996). Abnormal spermatogenesis in RXR beta mutant mice. Genes Dev 10(1), 80-92. http://dx. doi.org/10.1101/gad.10.1.80

Kirichok, Y., Navarro, B., \& Clapham, D. E. (2006). Whole-cell patch-clamp measurements of spermatozoa reveal an alkaline-activated Ca2 + channel. Nature 439(7077), 737-740. http://dx.doi.org/10.1038/nature04417.

Kozakov, D., Beglov, D., Bohnuud, T., Mottarella, S. E., Xia, B., Hall, D. R., et al. (2013). How good is automated protein docking? Proteins: Struct Funct Bioinf 81(12), 2159-2166. http://dx.doi.org/10.1002/prot.24403.

Kozakov, D., Brenke, R., Comeau, S. R., \& Vajda, S. (2006). PIPER: An FFT-based protein docking program with pairwise potentials. Proteins: Struct Funct Bioinf 65(2), 392-406. http://dx.doi.org/10.1002/prot.21117.

Landsteiner, K. (1899). Zur Kenntnis der spezifisch auf Blütkorperchen wirkenden Sera. Centralblatt 25, 546-549.

Lishko, P. V., Kirichok, Y., Ren, D., Navarro, B., Chung, J. -J., \& Clapham, D. E. (2012). The control of male fertility by spermatozoan ion channels. Annu Rev Physiol 74(1), 453-475. http://dx.doi.org/10.1146/annurev-physiol-020911-153258.

Liu, G. Z., Lyle, K. C., \& Cao, J. (1987a). Clinical trial of gossypol as a male contraceptive drug. Part I: Efficacy study. Fertil. Steril. 48(3), 459-461.

Liu, G. Z., Lyle, K. C., \& Cao, J. (1987b). Experiences with gossypol as a male pill. Am J Obstet Gynecol 157(4 Pt 2), 1079-1081.

Lubahn, D. B., Moyer, J. S., Golding, T. S., Couse, J. F., Korach, K. S., \& Smithies, O. (1993) Alteration of reproductive function but not prenatal sexual development after insertional disruption of the mouse estrogen receptor gene. Proc Natl Acad Sci U S A 90(23), 11162-11166

Makepeace, A. W., Weinestein, G. L., \& Friedman, M. H. (1937). The effect of progestin and progesterone on ovulation in the rabbit119(3), 512-516.

Mancini, R. E. (1976). Immunopathology of animal and human testes. In E. S. E. Hafez (Ed.), Human semen and fertility regulation in men (pp. 287-307). St Louis, Mo, USA: The C.V. Mosby Co.

Matzuk, M. M., McKeown, M. R., Filippakopoulos, P., Li, Q., Ma, L., Agno, J. E., et al. (2012) Small-molecule inhibition of BRDT for male contraception. Cell 150(4), 673-684. http://dx.doi.org/10.1016/j.cell.2012.06.045.

Maupetit, J., Derreumaux, P., \& Tufféry, P. (2009). PEP-FOLD: An online resource for de novo peptide structure prediction. Nucleic Acids Res 37(Suppl. 2), W498-W503. http://dx.doi.org/10.1093/nar/gkp323.

Maupetit, J., Derreumaux, P., \& Tufféry, P. (2010). A fast method for large-scale de novo peptide and miniprotein structure prediction. J Comput Chem 31(4), 726-738. http://dx.doi.org/10.1002/jcc.21365.

Metz, C. B. (1978). Sperm and egg receptors involved in fertilization. Curr Top Dev Biol 12 107-147.

Miki, K., Qu, W., Goulding, E. H., Willis, W. D., Bunch, D. O., Strader, L. F., et al. (2004) Glyceraldehyde 3-phosphate dehydrogenase-S, a sperm-specific glycolytic enzyme is required for sperm motility and male fertility. Proc Natl Acad Sci U S A 101(47), 16501-16506. http://dx.doi.org/10.1073/pnas.0407708101.

Mitra, A., Richardson, R. T., \& O'Rand, M. G. (2010). Analysis of recombinant human semenogelin as an inhibitor of human sperm motility. Biol Reprod 82(3), 489-496. http://dx.doi.org/10.1095/biolreprod.109.081331.

Morton, D. B., \& McAnulty, P. A. (1979). The effect on fertility of immunizing female sheep with ram sperm acrosin and hyaluronidase. J Reprod Immunol 1(1), 61-73.

Munoz, M. G., \& Metz, C. B. (1978). Infertility in female rabbits isoimmunized with subcellular sperm fractions. Biol Reprod 18(4), 669-678. http://dx.doi.org/10.1095/ biolreprod18.4.669.

O'Rand, M. G., \& Metz, C. B. (1974). Tests for rabbit sperm surface iron-binding protein and hyaluronidase using the "exchange agglutination" reaction. Biol Reprod 11(3), 326-334. http://dx.doi.org/10.1095/biolreprod11.3.326.

O'Rand, M. G., \& Romrell, L. J. (1977). Appearance of cell surface auto- and isoantigens during spermatogenesis in the rabbit. Dev Biol 55(2), 347-358.

O'Rand, M. G., \& Widgren, E. E. (2012). Loss of calcium in human spermatozoa via EPPIN, the semenogelin receptor. Biol Reprod 86(2), 55. http://dx.doi.org/10.1095/ biolreprod.111.094227.

O'Rand, M. G., Widgren, E. E., Beyler, S., \& Richardson, R. T. (2009). Inhibition of human sperm motility by contraceptive anti-Eppin antibodies from infertile male monkeys: Effect on cyclic adenosine monophosphate. Biol Reprod 80(2), 279-285. http://dx.doi. org/10.1095/biolreprod.108.072942.

O'Rand, M. G., Widgren, E. E., Hamil, K. G., Silva, E. J., \& Richardson, R. T. (2011) Epididymal protein targets: A brief history of the development of epididymal protease inhibitor as a contraceptive. J Androl 32(6), 698-704 http://doi.org/10 2164/jandrol.110.012781.

O'Rand, M. G., Widgren, E. E., Sivashanmugam, P., Richardson, R. T., Hall, S. H., French, F. S et al. (2004). Reversible immunocontraception in male monkeys immunized with Eppin. Science 306(5699), 1189-1190. http://dx.doi.org/10.1126/science.1099743.

O'Rand, M. G., Widgren, E. E., Wang, Z., \& Richardson, R. T. (2006). Eppin: An effective target for male contraception. Mol Cell Endocrinol 250(1-2), 157-162. http://dx.doi. org/10.1016/j.mce.2005.12.039.

Ochsner, A. J. (1899). Surgical treatment of habitual criminalsXXXII(16), 867-868. http:// dx.doi.org/10.1001/jama.1899.92450430021001d.

Ochsner, A. J. (1925). The surgical treatment of habitual criminals, imbeciles, perverts paupers, morons, epileptics, and degenerates. Ann Surg 82(3), 321-325.

Odet, F., Duan, C., Willis, W. D., Goulding, E. H., Kung, A., Eddy, E. M., et al. (2008). Expression of the gene for mouse lactate dehydrogenase C (Ldhc) is required for male fertility. Biol Reprod 79(1), 26-34. http://dx.doi.org/10.1095/biolreprod.108. 068353.

Paik, J., Haenisch, M., Muller, C. H., Goldstein, A. S., Arnold, S., Isoherranen, N., et al. (2014) Inhibition of retinoic acid biosynthesis by the bisdichloroacetyldiamine WIN 18,446 markedly suppresses spermatogenesis and alters retinoid metabolism in mice. J Biol Chem 289(21), 15104-15117. http://dx.doi.org/10.1074/jbc.M113.540211.

Pettersen, E. F., Goddard, T. D., Huang, C. C., Couch, G. S., Greenblatt, D. M., Meng, E. C., et al. (2004). UCSF chimera-A visualization system for exploratory research and analysis. J Comput Chem 25(13), 1605-1612. http://dx.doi.org/10.1002/jcc.20084.

Prajogo, E. W., B., Guliet, D., Queiroz, E. F., Wolfender, J. -L., Cholies, Z., et al. (2009). Isolation of male antifertility compound in N-butanol fraction of Justicia gendarussa Burm. F. leaves. Folia Medica Indones 45(1), 28-31.

Ren, D., Navarro, B., Perez, G. Jackson, A. C. Hsu, S., Shi, Q et al. (2001). A sperm ion channel required for sperm motility and male fertility. Nature 413(6856), 603-609. http://dx.doi.org/10.1038/35098027.

Richardson, R. T., Sivashanmugam, P., Hall, S. H., Hamil, K. G., Moore, P. A., Ruben, S. M. et al. (2001). Cloning and sequencing of human Eppin: A novel family of protease inhibitors expressed in the epididymis and testis. Gene 270(1-2), 93-102.

Rümke, P., \& Hellinga, G. (1959). Autoantibodies against spermatozoa in sterile men. Am J Clin Pathol 32, 357-363.

Sanchez, R., \& Zhou, M. -M. (2009). The role of human bromodomains in chromatin biology and gene transcription. Curr Opin Drug Discov Devel 12(5), 659-665.

Shen, Y., Maupetit, J., Derreumaux, P., \& Tufféry, P. (2014). Improved PEP-FOLD approach for peptide and miniprotein structure prediction. J Chem Theory Comput 10(10), 4745-4758. http://dx.doi.org/10.1021/ct500592m.

Silva, E. J. R., Hamil, K. G., \& O'Rand, M. G. (2013). Interacting proteins on human spermatozoa: Adaptive evolution of the binding of semenogelin I to EPPIN. PLoS One 8(12), e82014. http://dx.doi.org/10.1371/journal.pone.0082014. 
Silva, E. J. R., Hamil, K. G., Richardson, R. T., \& O'Rand, M. G. (2012). Characterization of EPPIN's semenogelin I binding site: A contraceptive drug target. Biol Reprod 87(3), 56. http://dx.doi.org/10.1095/biolreprod.112.101832.

Sneyd, M. J., Cox, B., Paul, C., \& Skegg, D. C. G. (2001). High prevalence of vasectomy in New Zealand. Contraception 64(3), 155-159. http://dx.doi.org/10.1016/S00107824(01)00242-6.

Sonnenberg-Riethmacher, E., Walter, B., Riethmacher, D., Gödecke, S., \& Birchmeier, C. (1996). The c-ros tyrosine kinase receptor controls regionalization and differentiation of epithelial cells in the epididymis. Genes Dev 10(10), 1184-1193. http://dx.doi.org/ 10.1101/gad.10.10.1184.

Tash, J. S., Attardi, B., Hild, S. A., Chakrasali, R., Jakkaraj, S. R., \& Georg, G. I. (2008a). A nove potent indazole carboxylic acid derivative blocks spermatogenesis and is contraceptive in rats after a single oral dose. Biol Reprod 78(6), 1127-1138. http://dx.doi.org/ 10.1095/biolreprod.106.057810.

Tash, J. S., Chakrasali, R., Jakkaraj, S. R., Hughes, J. Smith, S. K., Hornbaker, K., et al. (2008b) Gamendazole, an orally active indazole carboxylic acid male contraceptive agent, targets HSP90AB1 (HSP90BETA) and EEF1A1 (eEF1A), and stimulates Il1a transcription in rat Sertoli cells. Biol Reprod 78(6), 1139-1152. http://dx.doi.org/10.1095 biolreprod.107.062679.

Thévenet, P., Shen, Y., Maupetit, J., Guyon, F., Derreumaux, P., \& Tufféry, P. (2012). PEPFOLD: An updated de novo structure prediction server for both linear and disulfide bonded cyclic peptides. Nucleic Acids Res 40(W1), W288-W293. http://dx.doi.org/ 10.1093/nar/gks419.

Torgerson, D. G., Kulathinal, R. J., \& Singh, R. S. (2002). Mammalian sperm proteins Are rapidly evolving: Evidence of positive selection in functionally diverse genes. Mol Biol Evol 19(11), 1973-1980.

Torgerson, D. G., \& Singh, R. S. (2003). Sex-linked mammalian sperm proteins evolve faster than autosomal ones. Mol Biol Evol 20(10), 1705-1709. http://dx.doi.org/10. 1093/molbev/msg193.

Tyler, A. (1948). Fertilization and immunity. Physiol Rev 28(2), 180-219.
Tyler, A. (1961). The fourth Oliver Bird lecture approaches to the control of fertility based on immunological phenomena. J Reprod Fertil 2(4), 473-506. http://dx.doi.org/10. 1530/jrf.0.0020473.

Vitale, R., Fawcett, D. W., \& Dym, M. (1973). The normal development of the blood-testis barrier and the effects of clomiphene and estrogen treatment. Anat Rec 176(3), 331-344.

Waites, G. M. H., \& Setchell, B. P. (1969). Some physiological aspects of the function of the testis. In K. W. McKerns (Ed.), The gonads (pp. 649-714). New York: Appleton-Century-Crofts.

Wang, Z., Widgren, E. E., Richardson, R. T., \& O'Rand, M. G. (2007). Characterization of an Eppin protein complex from human semen and spermatozoa. Biol Reprod 77(3), 476-484. http://dx.doi.org/10.1095/biolreprod.107.060194.

Wang, Z., Widgren, E. E., Sivashanmugam, P., O'Rand, M. G., \& Richardson, R. T. (2005). Association of Eppin with semenogelin on human spermatozoa. Biol Reprod 72(5), 1064-1070. http://dx.doi.org/10.1095/biolreprod.104.036483.

White, C. W., Choong, Y. -T., Short, J. L., Exintaris, B., Malone, D. T., Allen, A. M., et al. (2013). Male contraception via simultaneous knockout of $\alpha 1 \mathrm{~A}$-adrenoceptors and P2X1-purinoceptors in mice. Proc Natl Acad Sci 110(51), 20825-20830. http://dx. doi.org/10.1073/pnas.1318624110.

Wyckoff, G. J., Wang, W., \& Wu, C. -I. (2000). Rapid evolution of male reproductive genes in the descent of man. Nature 403(6767), 304-309. http://dx.doi.org/10.1038/ 35002070 .

Yenugu, S., Richardson, R. T., Sivashanmugam, P., Wang, Z., O'Rand, M. G., French, F. S., et al. (2004). Antimicrobial activity of human EPPIN, an androgen-regulated, sperm-bound protein with a whey acidic protein motif. Biol Reprod 71(5), 1484-1490. http://dx.doi.org/10.1095/biolreprod.104.031567.

Youssef, H. (1993). The history of the condom. J R Soc Med 86(4), 226-228.

Zhen, Q. S., Ye, X., \& Wei, Z. J. (1995). Recent progress in research on Tripterygium: a male antifertility plant. Contraception 51(2), 121-129. 